\title{
CROSS-BORDER IDENTITY AS A DAILY RESISTANCE TACTIC OF COSMOPOLITANISM IN A TIME OF GLOBAL HEALTH EMERGENCY: GORIZIA-NOVA GORICA GO BORDERLESS
}

\author{
Giorgio Porcelli ${ }^{*}$ \\ ${ }^{1}$ Author affiliation: University of Trieste, Trieste, Italy \\ * Correspondent author: Giorgio Porcelli - giorgio.porcelli@scfor.units.it
}

Received: 22.1. 2021; Accepted: 26.3. 2021; Published: 17.5.2021

Doi: https://doi.org/10.46473/WCSAJ27240606/17-05-2021-0002

Category: Research paper

\begin{abstract}
Ulrich Beck represented cosmopolitan society as overcoming the nation-states as the container of the respective civil societies. In order to understand these profound changes, sociology itself appears inadequate, populated as it is by definitions that Beck considers as zombie concepts: "the conceptual apparatus of the sociology of modernity appears in crisis because it is inadequate to describe the situation of societies in which the borders of the nation-states that contained them have dissolved in an extremely rapid period. Rather than a definitive departure from that sociology, Beck's invitation to the international community of sociologists is to recalibrate their concepts in a cosmopolitan perspective» (Porcelli 2005: 8). The social contract, which was at the base of the construction of what Anderson defined the imagined communities, sanctioned the renunciation by the populations of part of their prerogatives of freedom favouring the security guaranteed by the sovereign power. The present global health emergency seems to have proposed the same social pact: more security and less freedom, especially people segregated within the resurging nation-states by new borders and walls. The remaining residue of globalisation is its economic-financial globalism. Ethnographic analysis along border areas reveals a consolidated crossborder identity experienced in people's everyday lives as a tactic of resistance against the erection of new self-containment barriers. This contribution aims to analyse the salient aspects of this phenomenon in the city of Gorizia, which for decades has constituted an integrated metropolitan area of the Italian and Slovenian zones, defining a specific cross-border identity shared by both Italian and Slovenian citizens. This identity has not given way in front of the walls that have been restored in recent months in order to contain the contagion and therefore could represent what de Certeau defined as a tactic of resistance that in the present case bears witness to the invention of an increasingly cosmopolitan daily life. In this respect, the main points of the project book submitted for the candidacy of Gorizia-Nova Gorica as European Capital of Culture 2025 will be examined. The title of the bid book itself specifies the cosmopolitan identity of the area under analysis: "Go borderless".
\end{abstract}

Keywords: European capital of culture, Go borderless, Gorizia, Nova Gorica, Italy, Slovenia 


\section{WORLD COMPLEXITY SCIENCE ACADEMY JOURNAL| Vol. 2 Issue 1, | Spring 2021}

\section{Gorizia and the myth of Mitteleurope: between past and future}

«In the early 20th century, Schoenberg was pushing the bounds of traditional triadic harmony, emancipating music from tonality and the keynote, and he was training a generation of younger composers, Alban Berg and Anton Webern among them, to follow his lead. Not surprisingly, performances of this music often rankled Vienna's conservative concertgoing public, and those who filled the Great Hall of the Musikverein on March 31, 1913 - both antagonists of the Schoenberg school, such as the operetta composer Oscar Straus, and a legion of supporters - must have sensed the possibility of trouble. Sure enough, the first disruption occurred soon after Schoenberg began conducting Webern's Six Pieces for Orchestra. Webern was only in his 20 s at the time, yet these six piecesdistilled, intense, lyrical, dissonant - would be one of his greatest achievements, one of several works he composed in memory of his mother, who had died several years before. Each of the six is a musical postcard of sorts: the first recalls the day a young Webern rode the train to his family's country estate in Carinthia and felt a presentiment of his mother's death; the second expresses the terror of realising that the premonition was true; the third evokes the discovery of a sprig of Erica blossoms, which he later placed on his mother's grave; the fourth depicts the funeral procession itself; the fifth and sixth pieces are a kind of coda, in which we hear the artist's inward retreat, his deep sense of melancholy. The audience was unaware of this hidden program, but would it have even mattered to those whose patience was tested by anything other than old-fashioned tonal music? The Six Pieces resulted in much shouting and laughter, which Schoenberg's adherents would not tolerate, and they now tried to drown out the loud, conservative voices with their vigorous applause. Alexander Zemlinsky's Four Orchestral Songs, based on poems by Maurice Maeterlinck, followed — opulent and tonal pieces that provided a temporary balm. However, perhaps this more conventional fare only threw into greater relief the difficulties of the work that came next: Schoenberg's own Chamber Symphony No. 1. Those who may have hoped for the lush, late-Romantic sounds of Gurrelieder or Verklärte Nacht were in for a shock. Schoenberg would later say that he had discovered his "own personal style of composing" in writing this innovative piece, which served as a bridge between his tonal and atonal periods. However, a large segment of the crowd was having none of it. The sound of Schoenberg's hyper-expressionist lines caused a good deal of hissing and whistling, and afterwards, the jangling of keys provoked a round of furious clapping from defenders of the work. In one of the balconies, the first fistfight of the evening broke out, accompanied by so much shouting that the next work on the program, two of Berg's Altenberg Lieder, could not be heard until some modicum of calm was restored. If Webern's reaction to the turmoil was one of defiance and anger, the younger Berg felt defeated, and indeed, he suffered a profound crisis of confidence as a result of what happened. It was not just Berg's dissonant music that provoked the bursts of laughter and general agitation. The texts of Peter Altenberg's poems had been printed in the program, and the overtly sexual nature of the lyrics-Have you seen the forest after the thunderstorms? / Everything sparkles, flashes, and is lovelier than before. / See, woman, you also need a thunderstorm! - appeared to scandalise even the least repressed of Berg's detractors. Schoenberg stopped the performance to scold the audience, and from the loge, Webern shouted out his disdain. The two factions in the crowd now battled with gusto, climbing over rows to get at each other. Faces were slapped, ears boxed, challenges to duel lustily issued. There were calls for Altenberg to be locked up in the Steinhof mental asylumfrom people who seem unaware that the poet was already institutionalised there. Erhard Buschbeck, the president of the association that had organised the concert, took to the stage, pleading with the crowd to restrain itself, respect the memory of the late Gustav Mahler, and sit still for the composer's Kindertotenlieder. Nothing doing - the brawl continued. Some bemused musicians, others frightened, remained on stage until they, too, were attacked, at which time Schoenberg decided it best to haul them all off. Mahler's song cycle would not be heard that day. Thus, the police were summoned to the hallowed, elegant Musikverein, and half an hour would pass before peace could be established and the hall finally cleared. At some point during the evening, Oscar Straus had been punched in the face; he later said that the crack to his jaw had been the most pleasant thing he had heard all evening» (Bose, 2017). 


\section{WORLD COMPLEXITY SCIENCE ACADEMY JOURNAL| Vol. 2 Issue 1, | Spring 2021}

The historical event mentioned above refers to the same cultural context that marks the background of the place we will analyse in this contribution: Gorizia, today a border town but part of the AustroHungarian Empire in 1913. The cultural identity was then that of Central Europe, an imagined community of peoples, languages and religions, and experience of multi-ethnicity more lived than desired. Gorizia-Görz-Gorica was designated with three different names, similarly to the other cities of the empire. The names corresponded to the languages spoken. The German version, which was the official language of political and economic power, was never missing. In addition to German, two other names corresponding to the majorities and ethnic minorities of the population that in 1913 in Gorizia were represented by the Slovenian and Italian components. The cards were inevitably shuffled at the end of the First World War and even more radically after World War II. Until 1945 Gorizia was not a border town. During the golden age of the Hapsburg Empire, the small town of Gorizia had been elected as the ideal place of residence for the retired officials of the imperial bureaucracy, which Musil (1996) ironically called Kakania. At the same time, however, it occupied a very special position for the Slovenian ethnic group. Slovenians did not participate in the 19th-century resurgence of the imagined communities of Central Europe. They remained loyal citizens of the Empire, which protected their linguistic and cultural specificity. The most important urban poles for the Slovenes were then LeibachLjubljana, Marburg-Maribor and Görz-Gorica. Ljubljana was the economic and commercial centre, while Gorizia was their small cultural capital for the Slovenes. Gorizia then found itself embodying the myth of Central European culture imbued with all ambiguities. As the history of SkandalKonzert has highlighted, it was a culture that was at the same time pushed towards the future of modernity and the look towards the past that characterised its inertia. New and old shared the same spaces, not without conflict. As far as the border identity of Gorizia was concerned, there was the silent and politically involved presence of the Italian minority. In that minority, especially significant were those elements that were part of the irredentist movement. The borderline until 1918 separated the territory of Gorizia from the Italian state. The geopolitical characteristics of that time do not allow the historian to speak about a border identity since Gorizia was the cultural capital of the Slovenian ethnic group that did not experience the condition of the border.

What happened from November 1918 was a very different story for Gorizia, together with Trieste and Trento. The German-speaking imperial component made up of civil and military bureaucracy abandoned the territories occupied by the Italian army and were waiting for the annexation to become official. For Italian Gorizia, this meant in the short term a reshuffling of the ethnic components. The place left free by the German-speaking officials of the empire, and their families were soon occupied by the civil and military officials of the Kingdom of Italy, often coming from the centre and the south of the peninsula. What had been a minority until 1918 suddenly became a majority while the Slovenian majority became a minority, and Gorizia cultural capital lost its privileged status. The twenty years of Fascism exasperated the Italianization of the territory by imposing as an official language Italian, whose learning was compulsory from primary school onwards and Slovenians (Vinci 2011). It was true that a kingdom of Yugoslavia had been constituted, but it was a political artifice to place those ethnic components that found no place in other nation-states that had arisen from the irredentism of the imagined communities of the nineteenth century.

For all these reasons, we believe that the concept of Anderson's Imagined Communities (2006) is crucial to our analysis: «Benedict Anderson's Imagined Communities was published in 1983, giving a breath of fresh air to a discussion of nationalism that had not seen really major new ideas in at least a generation. Analysis was mired in old debates over primordial identities vs invented traditions, nationalism as cultural inheritance versus a reflection of modern state-making, mere false consciousness, and powerful political factors. To the extent that each of these dichotomies posed a forced choice, Anderson took the second side. Nevertheless, more powerfully, Anderson subverted the dichotomies themselves, asking why newly made traditions should feel primordial, how modern state-making was able to produce a world in which cultural identities seemed powerful enough to be killed or kill for, and how constructed identities both rested on political economy and shaped social relations». Anderson's analysis poses a major intellectual challenge. The collective memory of the imagined communities is not simply a 


\section{WORLD COMPLEXITY SCIENCE ACADEMY JOURNAL| Vol. 2 Issue 1, | Spring 2021}

symbolic fact. The process of nation-building in 19th-century Central and Eastern Europe institutionalised national languages from dialects spoken by the humbler classes of the population into written languages, giving rise to literary and artistic movements to support the construction of the respective national identities. It was mostly a project carried out by the intellectual classes. Imagined communities gradually turned into living communities inhabiting territories, and borderlines began to be drawn to keep out and, in most cases, to expel those who did not recognise themselves in the emerging national identities. Collective memory is unfortunately often also the memory of bloodshed in the wars that followed. Imagined communities have been and perhaps still are in many contexts a divisive factor.

«A prominent translator, Gorizia born Ervino Pocar, once said: "Only in Gorizia a Slovenian professor can teach French in German to Italian students". Where have all those professors gone? Where are the students that a hundred years ago ran through the corridors of the famous Gorizia Staatsgymnasium, laughing and joking in four languages? » (Calhoun, 2016). This lucid observation describes not without bitterness the story that marked the events in Gorizia at least until the fall of the Berlin Wall. At the end of the Second World War, the city found itself divided by the Iron Curtain described by Churchill in his speech at Fulton in Missouri on March 5 1946: «From Stettin in the Baltic to Trieste in the Adriatic, an iron curtain has descended across the continent. Behind that line lie all the capitals of the ancient states of Central and Eastern Europe. Warsaw, Berlin, Prague, Vienna, Budapest, Belgrade, Bucharest and Sofia, all these famous cities and the populations around them lie in what I must call the Soviet sphere, and all are subject in one form or another, not only to Soviet influence but to a very high and, in many cases, increasing measure of control from Moscow» (International Churchill Society, 2021).

From that moment on, Gorizia began to live the reality of a border town in the most traumatic way. It was not an ordinary border but a barrier that divided two worlds and two spheres of geopolitical influence. Beyond the curtain, Tito's Yugoslavia aligned itself with the Moscow blockade despite the Marshal's distinction to guarantee a living space between the satellite countries. Gorizia ceased to be the multi-ethnic city described by Ervino Pocar.

\section{Gorizia and the border.}

Nova Gorica was founded in 1948, when, following the peace treaties after the Second World War, the border divided the city of Gorizia in two, and the eastern part of the city was assigned to Yugoslavia. Titus then decided to lay the first stone of a new urban settlement. He did not do so where the border divided Italian Gorizia from the small part of the town that became Yugoslavia within the federal republic of Slovenia. Nova Gorica was built on the other side of the Castagnevizza hill in the open countryside. The choice was not accidental. Nova Gorica would have represented an independent urban entity inhabited by the Slovenian ethnic group that belonged to the new Yugoslavia of Tito. In this way, an Italian Gorizia on one side of the Iron Curtain and a New Yugoslav Gorizia on the other side would have been opposed. The logic of the division would have been successful compared to the logic of collaboration. In everyday life, all this had dramatic repercussions on the existence of the citizens who lived together peacefully for centuries despite the different languages and cultures. In the bid book for the candidacy of Gorizia-Nova Gorica as European Capital of Culture, we read that: «Nova Gorica is a young city. In 1948, when the first foundation for a future regional centre was laid, politicians idealistically stated they were building something that will shine across the border. It was the post-war period, a time of healing, forgiveness, progress and hope, and a time of fierce ideological antagonism between east and west. The border Nova Gorica was supposed to shine across had been delineated a few months earlier at diplomatic tables in cities far from the region, and it was forced upon the population, Slovenian and Italian, as an artificial barrier. Suddenly both Italy and Yugoslavia provided a social construction of two different collective memories: «The concept of 'collective memory' thus tends to be understood as a set of social representations concerning the past which each group produces, institutionalises, guards and transmits through the interaction of its members. This definition, which was proposed more explicitly by Gérard Namer (cit. in Jedlowski, 2001:34) but later used by sociologists in general, allows us to study collective memory by concentrating on the processes that govern the formation, preservation and transmission of the content. This content may concern events that took place 


\section{WORLD COMPLEXITY SCIENCE ACADEMY JOURNAL| Vol. 2 Issue 1, | Spring 2021}

during the lives of the current members of a social group or events relating to a more remote past and may even incorporate the founding myths of the group itself. This memory reflexively adjoins and overlaps with the customs, practices and the very institutions in which the continuity of the group expresses itself, mostly in a non-reflexive manner, and performs the function of sustaining the sense of collective identity at the cognitive and symbolic levels (Connerton, cit. in Jedlowski, 2001: 34). Collective memory may take on a more or less institutionalised form, objectifying itself into specific practices in places of worship or artefacts. However, its origin and its reproduction are situated at the communicative practices that shape social life. These practices generate processes that considerably select the past and which may be based on consensual criteria or be the cause of conflict» (Jedlowski, 2001: 33-34)

Cutting through families where grandparents could not see their grandchildren grow up, cutting through stables where cows ate in Italy and slept in Yugoslavia, cutting through the living and the dead where the city was on one side and the cemetery on the other» (Municipality of Nova Gorica and Gorizia, 2020). Suddenly citizens were separated by geopolitical choices, which meant that the Slovenian ethnic group, in particular, had to choose which side they were on. Many decided to be the co-founders of what the Tito regime's propaganda celebrated as their city. Among them was my grandmother. Others stayed in Italy, not without the difficulty of undergoing a policy of cultural assimilation: «The narration of the history of Gorizia is mainly intertwined in two opposed discourses, built on the events connected to the two wars and the period after them. The Italian historical narration focuses on the speech of "Gorizia Città Santa", which recalls and praises the liberation of the Italian city and the entry of Italian troops on August 9, 1916. "Gorizia is the Holy City", as the poet Vittorio Locchi recited during the First World War, and it is then called the redeemed martyr city. Gorizia is finally free from the dominion of the Hapsburg monarchy. For this liberation, Italy sacrificed a great number of its children. The rhetoric of the sanctity of the city has its roots in the position of Gorizia after the First World War, when, at the end of October 1922, Italy proclaimed the area of the hills of San Michele and Sabotino as a Sacred Zone, in memory of all the fallen Italian soldiers. They sacrificed their lives so that Gorizia could be reunited with the motherland. The narrative of Gorizia as the holy city defines the myth of Gorizia as a martyr city. This speech exalts the heroism of the homeland and increases insignificance in the following decades, especially during the Second World War and the period of violence that marked Gorizia between 1943 and 1947, with particular reference to the tragic events of May 1945. Honouring all the tragic events that the city suffered, both in the First and Second World War before becoming Italian, the adjective "redeemed" suggests the great national value of Gorizia.

Conversely, the Slovenian historical narrative construction on the border area is different, mainly centred on Gorizia as a lost city. Gorizia was reunited with the territories divided by the Treaty of Rapallo and became Slovenian on May 1 1945. The end of the war is celebrated as a double liberation, both from the German occupation and from the Italian authorities before the Nazi government. The struggle for dominance over the territory of Venezia Giulia was much more complex. On May 1 1945, Yugoslav troops entered Trieste, Monfalcone and Gorizia, where they met with allied troops who entered the city the following day. Thus began the double military occupation and the disputed administration of the "liberated" lands. On June 12, 1945, the Treaty of Duino divided Venezia Giulia into two areas subject to military occupation administration: zone A, called Anglo-American (AMG) and zone B, administered by the Yugoslav Army. The city of Gorizia passed to the Allied Government (AMG), and the Yugoslav Army had to withdraw from the occupied/liberated areas. For national or ideological reasons, the part of the population welcomed the Yugoslav troops as winners and liberators, at the time of their departure in June 1945, showed their dissatisfaction by demonstrating in the streets of the city. Two years later, with the signing of the Peace Treaty, the city of Gorizia was definitively given to Italy. The Slovenian population, which had always resisted oppression and assimilation by fighting for its national identity, will remember until today the events of 1945 as the "loss" of Gorizia.

In historical texts and public debates, even regardless of their political orientation, the city of Gorizia appears therefore next to the verb "to lose". Regardless of the interpretations of the events after the Second World War, the issue is always about how Gorizia became a lost city. Both mnemonic 


\section{WORLD COMPLEXITY SCIENCE ACADEMY JOURNAL| Vol. 2 Issue 1, | Spring 2021}

communities use the past events to form various narratives about it, always intending to build and spread an "invented tradition", which legitimises the existence of the group in the territory. The narrations thus constructed make it clear that the line of demarcation is based on national identification and today's interpretation of the past" (Širok, 2016). Crossing the state border of the so-called Red House (Rožna Dolina) checkpoint was not an easy task even for the relatives. At least in the early years, the controls were not dissimilar from those to which the Berliners were subjected to cross Checkpoint Charlie. The comparison with the Berlin wall is not ephemeral since the first wall was erected in 1947 in Gorizia while the most famous one was built only in 1961. The expression Gorizia Wall (in Slovenian Goriški zid) was used in the press to describe a fence consisting of a $50 \mathrm{~cm}$ wide concrete base surmounted by a 1.5-meter railing built in 1947 and located along the Italian-Yugoslavian border passing through the city of Gorizia. The wall separated the remaining Italian town of Gorizia from the suburbs and the railway station of the Transalpina railway, which were annexed to Yugoslavia at the end of the Second World War.

\section{Gorizia beyond the border: cross-border identity and everyday life.}

In 2004, following Slovenia's entry into the European Union, the portion that divided the Transalpina into two squares was dismantled: «While presidents, generals and secretaries were preaching about victory and freedom and toasting to a new Europe, a group of children met in front of the Nova Gorica train station by the new border. They found a ball and played, tossing it over the barbed wire fence. A few feet away, people would walk along the border for hours, hoping to catch a glimpse of relatives and friends who, by twists of fate, remained on "the other side". The very same spot, the barbed wire playground, in 2004 was chosen by the European Commission to celebrate the enlargement of the European Union. The Mayors of Nova Gorica and Gorizia had removed the fence months earlier. People celebrated by passing a giant red ball over the disappearing border. Today citizens walk across the square freely. There is no visible sign of separation, and the border stone that once divided the two cities is encircled by a mosaic, work of a local artist» (Municipality of Nova Gorica and Gorizia, 2020: 5-6). It was started a slow process of cross-border policies in which the two entities that looked at each other from afar, not without mistrust, began to collaborate and build networks. The border from a barrier became a threshold, and from a threshold, the Transalpina square became an invisible border. An oval attracted the distracted tourist in the road surface that reminded him of a hidden history of the barrier that no longer existed.

History, however, is bizarre and tends to repeat itself. The recent crisis of the Covid-19 during March 2020 suddenly restored the borders, and the Transalpina square found itself again divided in two by a barrier of concrete and barbed wire. What happened during those three months, from March to June, despite the tragedy, was a powerful call to hope. The cosmopolitan identity of the Italian and Slovenian citizens of Gorizia emerged clearly through the suffering of a division that was perceived as an undesirable imposition. The media transmitted the moving images of families who, unable to celebrate their birthdays together, passed gifts from one side of the wall to the other, their eyes full of tears. When the borders were reopened in mid-June 2020, there was a celebration of a whole people. The words that introduce the recent candidacy of Gorizia-Nova Gorica as European Capital of Culture in 2025 are full of meaning: « If Slovenes and Italians in the Goriška region, heirs of bloody battles and vicious hatred, can go borderless, well, then everybody can do it. There are no excuses. It is going for the story that Nova Gorica and Gorizia can tell Europe» (Municipality of Nova Gorica and Gorizia, 2020: 5).

Cosmopolitan identity is, therefore, a convergent culture. Henry Jenkins defines convergence culture as the collision between the top-down and bottom-up cultural dimension (2006): «The term, participatory culture, contrasts with older notions of passive media spectatorship. Rather than talking about media producers and consumers as occupying separate roles, we might now see them as participants who interact with each other according to a new set of rules that none of us fully understands. Not all participants are created equal. Corporations - and even individuals within corporate media - still exert greater power than any individual consumer or even the aggregate of consumers. 


\section{WORLD COMPLEXITY SCIENCE ACADEMY JOURNAL| Vol. 2 Issue 1, | Spring 2021}

Furthermore, some consumers have greater abilities to participate in this emerging culture than others. Convergence does not occur through media appliances, however sophisticated they may become. Convergence occurs within the brains of individual consumers and through their social interactions with others. Each of us constructs our mythology from bits and fragments of information extracted from the media flow and transformed into resources through which we make sense of our everyday lives» (Jenkins 2006: 4). For emergence at the constitution of a new cultural identity, geopolitical projects are not enough if, at the same time, a culture of everyday life is not developed. Gorizia-Nova Gorica is a tangible example of such cultural convergence. It is a question of examining the stages of what Michel de Certeau called the practice of everyday life (1986): «A distinction between strategies and tactics appears to provide an adequate initial schema. I call a strategy the calculation (or manipulation) of power relationships that becomes possible as soon as a subject with will and power (a business, an army, a city, a scientific institution) can be isolated. It postulates a place that can be delimited as its own and serve as the base from which relations with an exteriority composed of targets or threats (customers or competitors, enemies, the country surrounding the city, objectives and objects of research, etc.) can be managed. As in management, every "strategic" rationalisation seeks first of all to distinguish its "own" place, that is, the place of its power and will, from an "environment." A Cartesian attitude, if you wish: it is an effort to delimit one's place in a world bewitched by the invisible powers of the Other. It is also the typical attitude of modern science, politics, and military strategy» (de Certeau, 1986: 35-36).

The practice of everyday life has its deep roots in what de Certeau called as tactics: «By contrast with a strategy (whose successive shapes introduce a certain play into this formal schema and whose link with a particular historical configuration of rationality should also be clarified), a tactic is a deliberate action determined by the absence of a proper locus. No delimitation of an exteriority, then, provides it with the condition necessary for autonomy. The space of a tactic is the space of the other. Thus, it must play on and with a terrain imposed on it and organised by the law of a foreign power. It does not have the means to keep to itself, at a distance, in a position of withdrawal, foresight, and self-collection: it is a manoeuvre "within the enemy's field of vision," as von Billow put it, and within enemy territory. Therefore, it does not have the options of general planning strategy and viewing the adversary as a whole within a district, visible, and objectifiable space. It operates in isolated actions, blows by blow. It takes advantage of "opportunities" and depends on them, being without any base where it could stockpile its winnings, build up its position, and plan raids. What it wins, it cannot keep. It is nowhere giving tactic mobility, to be sure, but a mobility that must accept the chance offerings of the moment and seize on the wing the possibilities that offer themselves at any given moment. It must vigilantly make use of the cracks that particular conjunctions open in the surveillance of the proprietary powers. It poaches in them. It creates surprises in them. It can be where it is least expected. It is a guileful ruse. In short, a tactic is an art of the weak» (de Certeau, 1986: 36-37). De Certeau supports the sociological perspective that Jenkins will later apply to the world of digital media. The concept of convergence culture is a development of the dichotomy-strategy tactics. Jenkins aims to emphasise the UGC's centrality (User Generated Contents) have assumed in the new media environment. Digital communication is made of grassroots content generated from below, produced by the user. The user is often a content poacher, i.e., he reworks uniquely and originally the messages transmitted by the traditional broadcast media. The new media domain is a convergence between top-down contents broadcasted by traditional communication professionals and user-generated bottom-up contents. Such contents must be strongly reiterated and solicited by the messages coming from the cultural industry. Users take possession of these contents to mix them, plunder them, redefine them, and produce new and original cultural objects. The application of de Certeau's theory elaborated by Jenkins is limited to the context of digital media. The dichotomy of strategies and tactics can spread much wider. It was probably the idea that de Certeau had already expressed in the title of The practice of everyday life. Tactics are declined in the context of everyday life. In continuity with the lesson of Pierre Bourdieu and his concept of practical human action, de Certeau thought of tactics as daily recipes for resistance to the strategies produced by the apparatuses of power. Bourdieu's pages in his anthropological studies to Kabylia culture in Algeria often dwelt on the humble operations carried out by farmers in their daily lives (Bourdieu, 1990). Culinary practices were examples of how the Kabylia culture was transmitted from one generation to the other and preserved 


\section{WORLD COMPLEXITY SCIENCE ACADEMY JOURNAL| Vol. 2 Issue 1, | Spring 2021}

from the assimilationist pressures of the hegemonic-dominant culture. De Certeau writes enlightening pages dedicated to the urban architecture that he considered a planning strategy to explore the wayfarer who invents his paths regardless of maps response. However, the tactics of participatory culture need to be put into practice in everyday life to become familiar. Meanwhile, the traditional power strategies of the nation-states will continue to exert their influence. As Jenkins writes in the closing pages of his book: «convergence culture is enabling new forms of participation and collaboration. For Levy, the power to participate within knowledge communities exists alongside the power the nation-state exerts over its citizens and corporations within commodity capitalism exert over its workers and consumers. For Lévy, at his most Utopian, this emerging power to participate serves as a strong corrective to those traditional sources of power, though they will also seek ways to turn it toward their ends. We are just learning how to exercise that power-individually and collectively — and we are still fighting to define the terms under which we will be allowed to participate. Many fear this power; others embrace it. There are no guarantees that we will use our new power any more responsibly than nation-states or corporations have exercised theirs. We are trying to hammer out the ethical codes and social contracts that will determine how we will relate to one another, just as we are trying to determine how this power will insert itself into the entertainment system or the political process. Part of what we must do is figure out how - and why - groups with different backgrounds, agendas, perspectives, and knowledge can listen to one another and work together toward the common good. We have a lot to learn» (Jenkins, 2006: 245-246).

\section{A call to a cosmopolitan and borderless identity.}

The cosmopolitan identity that has been built over the years in Gorizia has seen two distinct phases: the first from 1989 to 2004. It was a time of dramatic and decisive historical events. The collapse of the Berlin Wall put the Eastern Bloc countries in crisis, and the communist system ended with violence in post-Tito Yugoslavia. The federal republics that had constituted it claimed their independence from the central power in Belgrade. These were the years of the former Yugoslavia war that would crush the Marshal's utopia to ashes. Nova Gorica in this war represented a strategic point being located on the border. When the republic of Slovenia obtains its independence and recognition as a state entity by the international community, this was the decisive turning point for Gorica -Nova Gorica. Two forcibly divided urban entities began to interact. 2004 turned out to be the crucial year in which the wall of the Transalpina square would finally be demolished. It was a symbolic ritual that effectively sanctioned the birth of a new perspective made up of new cross-border policies. Until 2004 and afterwards, the story we have summarised is a narrative of strategies, in the meaning that de Certeau gave to the concept of strategy. What is missing or not very evident in that period is the practice of citizens' daily lives. In the second phase of the construction of the cosmopolitan identity, the years from 2004 to 2020 would have been crucial. The recent global crisis of Covid-19 has represented for Gorizia-Nova Gorica something different from what happened elsewhere. For many analysts, the pandemic has displayed both unexpected and unpleasant implications for the supporters of the idea of a cosmopolitan society. Where borders had been demolished, new health barriers appeared in their place that was even stricter and more impermeable. Countries worldwide rediscovered their outdated feature of nation-states that, like hedgehogs locked themselves away to protect their health and economic welfare interests.

The territory of Gorizia-Nova Gorica answered differently. The pandemic crisis was the litmus test of a consolidated cross-border and cosmopolitan identity: «In our flagship project EPICenter, we want to erect a building, which will be half in Italy and half in Slovenia. When 70 years ago the highest authorities in Yugoslavia planned the new city Nova Gorica, they wrote they want to build something which will "shine across the border". We want our EPICenter to shine across many borders as a symbol of collaboration, mutual respect and cultural enrichment. The starting point for an ambition, much bigger than the $\mathrm{ECoC}$ - to build the first European cross-border city, a trans-national conurbation, a project which, if successful, can radically change the way we see Europe. Yes, it is European bureaucracy. It takes ages and uses way too many words and excels tables. It can make a grown man cry. However, it is far better than a grave with a barbed wire fence» (Municipality of Nova Gorica and Gorizia, 2020). All this leads to the hypothesis that in the period from 2004 to 2020, a repertoire of tactics decisive either 


\section{WORLD COMPLEXITY SCIENCE ACADEMY JOURNAL| Vol. 2 Issue 1, | Spring 2021}

to the practice of everyday life or to the resistance of the cross-border identity has been consolidated: "The other side" is where you go for a good coffee with a dear friend, to buy a loaf of bread or a pair of jeans. Of course, the enlargement of the Union was made possible by great structural changes throughout the continent.

Nevertheless, people along the border overcame conflicts and hatred all by themselves, long before global political powers realised it was time for the walls to fall. Through decades of joint work in associations, cultural, educational and economic institutions and small everyday gestures, though scarred by the horrors of war, people of Gorizia and Nova Gorica drilled a hole in the iron curtain. They managed to build a friendship, which is real, sincere and vibrant» (Municipality of Nova Gorica and Gorizia, 2020: 6).

The newly formed neighbourly relations led to the ambitious project that, with the candidacy of GoriziaNova Gorica as European Capital of Culture 2025, would like to break the last barrier still existing to separate the Italian and Slovenian ethnic groups, that is, the spoken language.: "This konfin is about challenging the Babylon tower in the land of so many languages, about all our codes of communication: body language, digital language, sign language, clown language... However, the first goal is to achieve passive bilingualism between the citizens of the two cities. In a way that anyone may speak their language and the other will understand. We strongly believe that only when we reach this reciprocity level can we truly create a common cultural space. With special attention toward minorities, not only the Slovenian one across the Italian border but minorities all over Europe, we will show that the mix of cultures is as much a natural state of Europe as is the national cultures/languages" (Municipality of Nova Gorica and Gorizia, 2020: 23). Once more, the proposal is to develop inclusion projects through the social construction of reality. The sociological theory of reference is declined at the micro-level. Once again, it echoes the tactics of de Certeau and Bourdieu's habitus: «I have explained the meaning and function of the concept of habitus so often that I hesitate to return to it once more, lest I only repeat myself and simplify without necessarily clarifying things. . . All I want to say here is that the main purpose of this notion is to break with the intellectualist (and intellectual centric) philosophy of action represented (...). I wanted initially to account for practice in its humblest forms - rituals, matrimonial choices, the mundane economic conduct of everyday life, etc.- by escaping both the objectivism of action understood as a mechanical reaction "without an agent" and the subjectivism which portrays action as the deliberate pursuit of a conscious intention, the free project of a conscience positing its ends and maximising its utility through rational computation» (Bourdieu and Wacquant 1992: 120-121).

On the other hand, the territory of Gorizia has experienced the tragedy of cultural assimilation, particularly on the Italian side. This event has exacerbated for many decades the conflict between the Italian majority and the harassed Slovenian minority. When the border barriers disappeared in 2004, three ethnic components found themselves interacting: the Italian side, the Slovenians from Nova Gorica and the Slovenian minority from Gorizia. The reconstruction of the multi-ethnic social fabric could only restart at everyday life practices without difficulty. The collective memory suffered and still suffers from unhealed wounds. Intercultural communication is a process that does not disregard the conflict generated by diversity.: «It sounds strange, but each member of the Slovenian minority in Gorizia has two birthplaces: one is called Gorica, the other Gorizia. Gorica speaks, reads, thinks and dreams in Slovene and Italian, and Gorizia speaks only Italian. For decades, Slovenes in Italy have been a thorn in the side of the country because of their demand for special protection. They were a problem in the bilateral talks between Italy and Yugoslavia and Slovenia after its independence. After obtaining legal protection in 1999 and 2001 and following the enlargement of the European Union in 2004 and Schengen in 2007, the community is searching for a normal life. As members of an integrated national community and Italian citizens, they are embedded in the environment of the majority nation. Therefore, they are confronted with the everyday problems that the Italian majority has. Some members of the minority fight the silent assimilation - they are a minority inside the minority, but structured, with its institutions and media, represented (until when?) in Rome, in the regional government and in the municipalities which, in the face of the gradual degradation of identity, also results in the lack of innovative force and the passive preservation of what already exists. We want to create "a third space" beyond national 


\section{WORLD COMPLEXITY SCIENCE ACADEMY JOURNAL| Vol. 2 Issue 1, | Spring 2021}

identities. Help the Slovenian minority and all of us citizens of GO out of the language-ideology trap and hostages-of the-past-trap. Taking the schizophrenic existence out of being a "minority" in your birth country and being a "foreigner" in your supposed "home" country. If the Slovenian minority can live equally well in Milan and Ljubljana - perhaps that will be the day where we can all realise the ideal of European linguistic and cultural pluralism» (Municipality of Nova Gorica and Gorizia, 2020: 38).

«Europe needs new words, honest words, lots of them. The joyful ones and the painful ones. Nova Gorica and Gorizia are perfect for the job because the building, destroying, rebuilding, painting, bypassing, imagining, idealising and cursing walls and fences is essentially what we have been doing for the past couple of centuries. On the other hand, we are a perfect example of why borders are the last thing any modern European should aspire to. Furthermore, we are in desperate need of reminding ourselves the very same thing. » (Municipality of Nova Gorica and Gorizia, 2020: 37).

«We want to build a house with foundations in two countries. The ultimate European house. A material proof of what can we achieve if we decide to work together and give our European Union a fair chance. In a growing atmosphere of distrust toward EU institutions, in the shadow of Brexit and rising euro sceptical populist political movements, we want to emphasise the worth and benefits of European legal and financial mechanisms. We want to explore these tools, which might be evolving and imperfect but have already given extraordinary results and hold immense potential for the future. Nova Gorica and Gorizia show that European mechanisms, though they are complicated, heavy and boring beasts, actually work. Our European Grouping of Territorial Cooperation, the EGTC GO, has managed to invest ten million euros in shared projects, proving it is possible to take transnational collaboration to a whole new level. GO! Borderless has chosen the EGTC as a delivery platform with the ambition to create an example of good practice» (Municipality of Nova Gorica and Gorizia, 2020: 38). The existence of a boundary has always been (and still is) considered an obvious assumption for constructing the identity of a system. In intercultural communication, however, the border is considered an obstacle to the reciprocal intercultural adaptation and a cause of ethnocentric conflicts. While in a hierarchical society, the boundaries produce a sense of safety and are a warning against the possible crises of an ethnic identity that needs to be defended. In a multi-coding society, the boundaries between cultures create claustrophobia, a sense of compulsion. In this sense, the creation of borders indicates a negative closure, as evidenced by the fact that geographical boundaries are used to separate and define spaces for conquest and possession and that one of the first measures indicating a new union or collaboration is their opening. Boundaries overwhelm the openings to the possible multiplicity of cultural expressions. One of the most interesting attempts is well represented by the concept of threshold (Richter and Malabotta, 2002). We should expect the suspended step of the stork of those who, for their biography, is ideally located on the threshold of a no-man's land that separates the different cultural worlds: it is an openness that evokes the dissolution of the borders. The suspended step of the stork is the title of a film of the Greek director Theo Anghelopulos and refers to the communicative action of a commander of a troop on a frontier with a hostile country: to show a journalist the meaning of his role, the commander raises a leg and suspends it on the borderline, while a soldier on the other side of the raider aims with his gun, ready to shoot as soon as the man crosses the border. The commander comments on his gesture, observing that a step beyond the border means either to be on the other side or to be dead» (Baraldi, 2003:168). Creating a threshold means setting the conditions for a border passage: the threshold is the non-place, a state of suspension of the difference. The suspended step of the stork symbolises the suspension of the situation on the border and the consequent needs to stand on one side or the other, which is the essence of ethnocentrism (normative or modernist) as a form of intercultural communication. The threshold is the place where the suspended step of the stork acquires meaning. The thresholds are spaces «where either the encounter and the contact are facilitated and the pretext of cancelling the border» (Baraldi, 2003: 15). Opening the borders and creating thresholds between cultures is not a simple or painless operation: it evokes the modernist and individualist idea that losing a cultural identity should be a major problem. Were borders abolished, cultural diversity should be missing and, therefore, a new monoculture determined. In communication, borders appear to be a guarantee of maintaining cultural diversity and are considered essential to foster intercultural communication. The concept of threshold indicates the 


\section{WORLD COMPLEXITY SCIENCE ACADEMY JOURNAL| Vol. 2 Issue 1, | Spring 2021}

abolition of an ethnocentric boundary that creates inequality or discrimination. However, it is not easy to distinguish this type of boundary from those who maintain cultural diversity and/or offer guarantees of reproducing other forms of communication. For this reason, it is important to clarify the form of intercultural communication that ensures the opening and the creation of thresholds, that is, the reconstruction of the boundary of adequate communication (Baraldi, 2003: 168-170). All these statements have moulded the practices of everyday life of the citizens of Gorizia-Nova Gorica territory, shaping a specific and original cross-border culture: «A central impetus to the development of everyday life sociology was the growing dissatisfaction in mid-twentieth-century social thought with the approach contained in classical and contemporary macro theory. Both positivism and critical sociology were seen as overly deterministic in their portrayal of the individual in society: The actor was depicted as either a tabula rasa, internalising the norms and values of society out of a desire for group membership, or as a homo economicus, developing social, political, and ideological characteristics as a result of his/her class membership. As a result, these traditional approaches generated an overly passive and constrained view of the actor» (Adler, Adler and Fontana, 1987: 218). What happened not only in recent decades, but especially in the months of isolation imposed by the recent pandemic, testifies as if there was still a need for it, not the passivity of a constrained social actor, but an active and strong citizen with a cosmopolitan identity-built day after day in the humble practices of everyday life.

\section{Conclusion}

Far from representing a folkloristic cultural heritage of anthropological interest, what has recently occurred in the cross-border territory of Gorizia, whose foundations are rooted in the myth of Mitteleuropa, is of capital importance: the candidacy of Gorizia as European Capital of Culture 2025 is a call to Europe and the whole world. Despite the new barriers raised everywhere as a health containment measure, Gorizia-Nova Gorica remains a borderless area. The lifeblood of this programme is not the result of ideology or planning. These are not strategies but tactics, behaviours that have slowly spread and shared by the entire population. We are talking about those practices of everyday routine through which the inhabitants of the territory of Gorizia have learnt to live in their border area, despite the barriers and beyond the barriers to the point that the border at a certain point has disappeared. One day in 2004, the barrier that divided the Transalpina square ceased to exist simply because of the repossession of the square as a place of passage and daily meeting. The importance of Gorizia's borderless role at the moment cannot be overemphasised; it is a role both desired and lived by its citizens in the daily exchanges and interchanges between the Italian and Slovenian ethnic groups and the different ethnic minorities that populate that area today. Gorizia-Nova Gorica testifies that its cosmopolitan identity is not dying despite those who declare it sacrificed on the altar of global geopolitics. The magnifying glass of the sociologies of everyday life and the collective memory is of paramount relevance to analyse at a micro level what is happening in the interstices of everyday life. Small and maybe little clues but of fundamental significance to shore up a global perspective that can exist in its own right only accompanied by a cosmopolitan eye. It is not going for the theorist's eye, but that of the citizen who sees and above all lives a story that others cannot grasp, and that is a story that is waiting and claiming to be told.

\section{References}

Adler, P.A., Adler, P., and Fontana, A. (1987), "Everyday Life Sociology", Annual Review of Sociology, Vol. 13, pp. 217-235.

Anderson, B. (2006), Imagined Communities. Reflections on the Origin and Spread of Nationalism. Verso, London, UK.

Baraldi, C. (2003), Comunicazione interculturale e diversità. Carocci, Roma, IT.

Bourdieu, P. (1990), The Logic of Practice. Polity Press, Cambridge, UK. 


\section{WORLD COMPLEXITY SCIENCE ACADEMY JOURNAL| Vol. 2 Issue 1, | Spring 2021}

Bose, S. (2017), "Sound and Scandal", The American Scholar, available at: https://www.wcsaglobal.org/guidlines/ (accessed 4. August 2020).

Bourdieu P. and Wacquant L.J.D. (1992), An Invitation to Reflexive Sociology. University of Chicago Press, Chicago, US.

Calhoun, C. (2016), "The Importance of Imagined Communities and Benedict Anderson Debats", Journal on Culture, Power and Society, No.1, pp. 11-16.

De Certeau, M. (1984), The Practice of Everyday Life. University of California Press, Berkeley, US.

Jedlowski, P. (2001), "Memory and Sociology", Time \& Society, Vol. 10, No. 1), pp. 29-44.

Jenkins, H. (2006), Convergence Culture. Where Old and New Media Collide. New York University Press, New York, US.

Municipality of Nova Gorica and Gorizia (2020), "The GO! 2025", available at: https://www.go2025.eu/wp-content/uploads/2020/04/BidBook_ENG_1-web-small.pdf(3th May 2021). Musil, R. (1996), The Man Without Qualities, Volume 1. Vintage Books, New York, US.

Porcelli, G. (2005), Identità in frammenti. Prospettive globali di sociologia della conoscenza. Franco Angeli, Milano, IT.

Richter Malabotta, M. (2002), "Vivere le terre di mezzo", Piccioni L. (Ed.), Sconfinare. Differenze di genere e di culture nell'Europa di oggi, Edizioni Goliardiche, Urbino, IT.

Širok, K. (2016, 1st June), "La fragilità della memoria. Il ricordo e l'identità nel goriziano", Qualestoria, No. 1, pp. 125-126.

Vinci, A. (2011), Sentinelle della patria. Il fascismo al confine orientale 1918-1941. Laterza, RomaBari, IT.

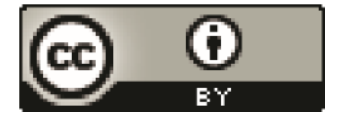

This article is distributed under the terms of the Creative Commons Attribution 4.0 License (https://creativecommons. org/licenses/by/4.0/) which permits any use, reproduction and distribution of the work without further permission provided the original work is attributed as specified on the WCSA Journal by World Complexity Science Academy (https://www.wcsaglobal.org/ethics-policy/). 